\title{
STRATEGY FOR THE DEVELOPMENT OF WAREHOUSE LOGISTICS AS A COMPONENT OF TRANSPORT AND LOGISTICS SYSTEMS IN THE FOCUS OF ECONOMIC TRANSFORMATION
}

\author{
Sergii Voit ${ }^{1}$, Inna Irtyshcheva ${ }^{2}$, Anatoly Nosar ${ }^{3}$
}

\begin{abstract}
The subject of the study is the theoretical and methodological aspects of the development strategy of warehouse logistics as a component of transport and logistics systems in the focus of economic transformation. Methodology. General scientific methods used in the study, in particular: theoretical generalization; methods of positive and normative analysis, statistical analysis. The purpose of the work is to substantiate the strategy of development of warehouse logistics as a component of transport and logistics systems in the focus of economic transformation. Results. The article substantiates the development strategy of warehouse logistics as a component of transport and logistics systems in the focus of economic transformation. The main components of the development strategy of logistics management at the macro-, meso- and micro-levels are revealed. The main directions of development of transport and logistics system of Ukraine in the context of European integration. It is emphasized that the multiplier effect of investment in transport and logistics does not work by itself, but requires effective management of the regional economy, a high level of business activity in the leading sectors of the regional economy and successful spatial planning. The identified multiplier indicators and their trends in the regions show that investment in the development of transport and, in particular, infrastructure is one of the important incentives for regional economic development. At the same time, the investment acceleration indicators in the dynamics show a downward trend in all regions, which indicates the insufficient level of funding for transport and logistics support against the background of the gradual growth of the regional economy. The article substantiates a system model for assessing the level of development of the transport and logistics system in the region. The structural model of the development strategy of regional warehousing logistics has been proposed. To clarify the nature, main tasks and role in the development of transport and logistics structures in the region, a structural model of the development strategy of warehouse logistics, which systematizes: the conditions necessary to build a warehouse infrastructure and organize logistics activities in the region; identified alternatives for the necessary scale, technology placement and communications of warehouse systems, as well as the types and forms of organizational links between market participants, which are directly or indirectly related to this activity.
\end{abstract}

Key words: strategy, warehousing logistics, transport and logistics systems, economic transformations.

JEL Classification: F01, R14, Q28, Q29

\section{Introduction}

In the current context of globalization, internationalization and transformation of markets, the role of transport and logistics systems and corresponding logistics centers in ensuring economic development, security and competitiveness of the economy at the global, national and regional levels is increasing.
Thus, global trends in the development of transport and logistics systems include the integration of transport, information technology, and regional mobility projects. In this case, warehouse systems play the role of integrating the created elements of transport and logistics complexes and the level of their organization, manufacturability, standardization and

\footnotetext{
Corresponding author:

${ }^{1}$ State Enterprise "Production Association Yuzhny Mashinbuilding Plant named after A. M. Makarov", Ukraine.

E-mail: management@nuos.edu.ua

ORCID: https://orcid.org/0000-0001-9566-3090

${ }^{2}$ Admiral Makarov National University of Shipbuilding, Ukraine.

E-mail: innauamd@gmail.com

ORCID: https://orcid.org/0000-0002-7025-9857

${ }^{3} \mathrm{CEO}$ at Movingcalifornia.com, Ukraine.

E-mail: management@nuos.edu.ua

ORCID: https://orcid.org/0000-0001-6225-5277
} 
compliance with the needs of the logistics market is one of the important factors in assessing the logistics competence of the country and individual regions.

Due to the small number of warehouses, there is a need for perfect management. Warehouse logistics management should be based on the basic functions of management: planning, organization, coordination and control. The efficiency of warehouse management will depend on the implementation of certain functions. Therefore, the proper role in the management of warehouse logistics belongs to planning. The efficiency and effectiveness of the entire system will depend on the tasks of warehouse logistics planning. The main tasks of comprehensive logistics planning include: distribution of work areas and equipment on them in order to minimize costs, increase the level of cargo handling and warehouse capacity, and increase throughput capacity.

An important role in the planning of warehouse logistics belongs to the reduction of costs associated with document flow. Therefore, a significant place in the development of warehouse logistics belongs to the means of informatization and automation, which will significantly speed up shipment time and contain all information in the appropriate database (platform). Among the main vectors of development in the field of warehouse logistics in Ukraine should be noted: the development of state and regional programs of functioning of warehouse logistics, to introduce highquality services in logistics expansion of material and technical base (Class A warehouses), reducing overhead costs, energy costs by increasing the share of automation and digitization throughout the logistics chain. That is why improving the strategic approach to warehouse logistics management plays an important role in today's environment.

\section{Justification of the main components of the logistics management development strategy at the macro-, meso- and micro-levels}

The analysis of logistics efficiency subindices shows on a 5-point scale the main strengths and weaknesses of transport and logistics systems in comparison with similar ones in other countries. The highest for the period under study are the indicators of the timeliness of cargo delivery, which positively characterize Ukraine as a transit service. Ukraine also has above-average scores on the sub-indices of freight transportation on average (2.80 points) and freight tracking systems (3.15). Compared to the previous period, the transport infrastructure score decreases (from 2.69 to 2.2 points), which is primarily due to the depreciation of fixed assets in the industry and the condition of the road surface. The assessment of the customs service is the lowest because of inefficient administrative procedures and a high level of corruption. Based on these indicators, we see that the current logistics potential of Ukraine is used on average 2.83 points out of 5 , and the structure of the overall coefficient reveals the main weaknesses of the system, including bureaucracy, limited and inefficient investment, lack of qualified personnel, the lack of pace of innovation technologies and European standards of logistics services.

As Ustenko M. A. notes, "Participation in the globalization of the transport services market for the transport system of any state means:

- active development and modernization of transport infrastructure, unification and universalization of vehicles, technologies, technical requirements;

- abandonment of state regulation, which leads to the liberalization of all areas of transport, and thus to increased competition;

- subordination of the activities of transport companies to the requirements of legislation and international agreements, increasing the transparency of the transport services market, increasing informational openness (including financial)" (Ustenko and Ivashkevich, 2017).

The development of logistics activities in Ukraine and promising opportunities for further growth of its share in GDP are determined by the following factors: - geographical location and available transit potential; - availability of an extensive transport network represented by all types of transport (road, air, rail, waterborne);

- agricultural development;

- growth of the trade and retail trade sector;

- increase in the e-commerce market;

- development of information and computer technologies and development of the communications sector.

All of these factors combine to form a growing need for the development of a professional logistics market and the development of logistics infrastructure.

At the same time, the paper agrees with the authors Parkhaeva N. V. and Kolosova B. V. that "Today Ukraine significantly lags behind the global level of development of logistics systems, and the deterrent factors include: the lack of road network development, the lack of modern freight terminals, the high level of depreciation of road, rail and other types of transport fleet, as well as its increasing obsolescence; a small number of high-quality modern warehouses with the necessary specialized equipment to meet global logistics needs; the low level of implementation of communication systems, due to which many logistics companies have difficulties in tracking logistics chains and the process of transporting goods across the country and abroad; poor development of the industry for the production of modern containers and packaging; an acute shortage of qualified professionals who are well-versed in modern principles of the 
organization of logistics schemes to promote material flows and have the skills to respond quickly to changing market conditions; the lack of an effective mechanism of partnerships between firms and enterprises" (Parkhaeva and Kolosova, 2020).

Research shows that despite the growing attention of state authorities and local governments to the development of transport infrastructure of territories, little attention is paid to the issue of warehouse logistics in strategic documents. The main objectives of strategies at all levels are, above all, the development of transport infrastructure (repair of roads, ports, modernization of airports and railway infrastructure).

The authors believe that additional attention and stimulation of warehouse logistics development will increase business activity in the region and help solve a number of important issues, including economic (increased profitability of priority sectors of economic activity by reducing logistics costs, increased tax revenues to local budgets), social (employment growth, food security, human capital development) and environmental (construction of storage facilities in areas that do not have a significant impact on the environment, safety and quality control of transport and storage technology).

This area of activity in Ukraine is considered a business problem, as entrepreneurs are interested in building and equipping warehouses in accordance with the directions of business development. However, without the necessary conditions business will be limited to minimum investment to maintain a certain level of production and sales. Indirectly, some areas of warehouse logistics are mentioned in strategic documents such as the "National Transport Strategy to 2030", "Draft Strategy of Sustainable Logistics and the Government Action Plan", "Strategy for reforming the life cycle management of infrastructure projects in Ukraine 2020-2024", as well as the State Regional Development Strategy for 2020-2027 and the Strategy of Social and Economic Development of regions until 2027.

In particular, the Transport Strategy outlines the main objectives of the development of transport and logistics system of Ukraine, including the development of warehouse logistics:

- implementation of a mechanism to stimulate the gradual modernization and development of transport infrastructure, renovation of vehicles for the needs of the industry, including the improvement of the management system of transport infrastructure development and implementation of the transport network development plan based on the national transport model;

- introduction of an effective tax mechanism to attract private capital to the development of various types of transport;
- legislative improvement of the mechanism for the use of public-private partnerships in the implementation of transport infrastructure development projects;

- transition to planned and stable financing of road construction and maintenance in the medium and long term;

- improvement of legislation to develop a simplified mechanism for the seizure and redemption of land for the development of transport infrastructure, the concession of land for road construction and the registration of enterprises and organizations for the transport of land for use;

- improvement of legislation and economic mechanism that promotes localization of the best innovative technologies for construction of transport infrastructure, production and renovation of rolling stock on the basis of domestic enterprises, in particular stimulating the development of their foreign economic activity by establishing customs privileges;

- development of a transparent mechanism for prioritizing public procurement, their justified technical and economic feasibility, cost-benefit analysis;

- implementation of long-term financial planning for the implementation of infrastructure projects in the transport sector in accordance with the strategic priorities, implementation timeframe and life cycle of transport facilities with the priority of projects related to the TEN-T network;

- creation of a unified system for coordinating, planning, attracting and monitoring international aid for the effective allocation of investments in accordance with the priorities for the development of the transport industry.

In the regional dimension, warehouse logistics is seen as an important component and one of the leading business processes of transport and logistics systems. Therefore, the strategy for the development of warehouse logistics can act as a cross-cutting project in the strategy for building transportation and logistics systems in the region and most effectively located in relation to the main objects of demand for the corresponding warehouse services.

Thus, the strategy of warehouse logistics is undoubtedly an important component of the transport and logistics infrastructure of the region and the national economy as a whole, and the effectiveness of its organization affects the formation of the logistics strategy of enterprises and determines the efficiency of their business processes. That is why an important task is to identify the main components influencing the strategic location and level of development of warehouse infrastructure at the macro-, meso- and macro-levels, to assess the main mechanisms of influence of these factors and determine the key tools to stimulate this type of economic activity. Figure 1 systematizes the main factors that directly or indirectly influence the 
development of storage infrastructure in the regions and its specification in accordance with regional needs.

The National Transport Strategy defines the main government priorities in the development of transport infrastructure in accordance with the strategic needs of the national economy, taking into account international relations of the country and the framework conditions for international cooperation in this area.

An important element of the national strategy for the development of transport and logistics systems at the state level is also the development of international cooperation in this area, which determines the place of the state in the organization of international transport and logistics flows. In particular, the main strategic priorities and principles of the development of the transport system of Ukraine in the framework of the signed Association Agreement between Ukraine and the European Union were discussed.

The team of authors notes that "One of the main areas of national security of the country, a means of preserving its sovereignty and independence, a necessary condition for the implementation of strategic national priorities to ensure a high standard of living of the population is the food security of the country" (Irtyshcheva, Ponomarova \& Dolzhykova, 2019).

Table 1 systematizes the main principles of development of transport and logistics system of Ukraine, aimed at harmonization and integration of domestic transport and logistics systems in the European network.

Macro-level factors affecting the development and arrangement of storage infrastructure include the Strategy for reforming the life cycle management of infrastructure project in Ukraine for 2020-2024, developed by the Cabinet of Ministers of Ukraine, taking into account the provisions of the Association Agreement between Ukraine and the European
Union. The purpose of the Strategy is to improve the management of the life cycle of infrastructure projects implemented in the field of transport and logistics, the removal of barriers to the effective management of infrastructure projects in Ukraine and the elimination of limiting factors for the sustainable development of transport systems. The implementation of the Strategy provides for the implementation of the following measures:

- improvement of the system of coordination of investment management in the transport sector;

- ensuring the development of transport infrastructure within a single (unified) system of long-term and medium-term planning;

- improving the process of preparation, evaluation and selection of investment projects in the field of transport in accordance with international experience;

- an agreed definition of terminology, stages and procedures for infrastructure projects to eliminate technical barriers and ensure effective international cooperation;

- implementation of the management model for infrastructure projects at all stages of their life cycle in accordance with ISO 21500: 2012 "The project management manual";

- improvement of the monitoring system of the infrastructure project during its life cycle;

- introduction of independent engineering supervision of construction;

- introduction of standard forms of contracts and agreements for the provision of engineering services, ensuring the mandatory use of internationally recognized forms of contracts in the field of construction;

- definition of requirements for business entities providing engineering services in accordance with the European experience, ensuring conditions for the formation and development of the engineering services market;

Table 1

The main directions of development of the transport and logistics system of Ukraine in the context of European integration

\begin{tabular}{|l|l|}
\hline \multicolumn{1}{|c|}{$\begin{array}{c}\text { Directions for the development } \\
\text { of transport and logistics systems }\end{array}$} & \multicolumn{1}{c|}{ International agreements } \\
\hline $\begin{array}{l}\text { Implementation of projects to attract financial } \\
\text { instruments and funds of EU financial } \\
\text { institutions }\end{array}$ & $\begin{array}{l}\text { - International technical assistance of the EU in the field of transport } \\
\text { - Cooperation with EU thematic programs and agencies in the field of air, sea, river and } \\
\text { rail transport }\end{array}$ \\
\hline $\begin{array}{l}\text { Cooperation in the field of harmonization of } \\
\text { legislation and existing standards }\end{array}$ & $\begin{array}{l}\text { - Association Agreement between Ukraine and the European Union, the European } \\
\text { Atomic Energy Community } \\
\text { - Regulatory framework of Ukraine on the adaptation of Ukrainian legislation in the } \\
\text { fields of transport, tourism and postal services to the EU legislation }\end{array}$ \\
\hline $\begin{array}{l}\text { Participation in regional EU projects in the field } \\
\text { of transport and logistic }\end{array}$ & $\begin{array}{l}\text { - Eastern Partnership } \\
\text { - EU Strategy for the Danube Region } \\
\text { - Interregional Program TRACECA }\end{array}$ \\
\hline
\end{tabular}

Source: systematized by the authors 


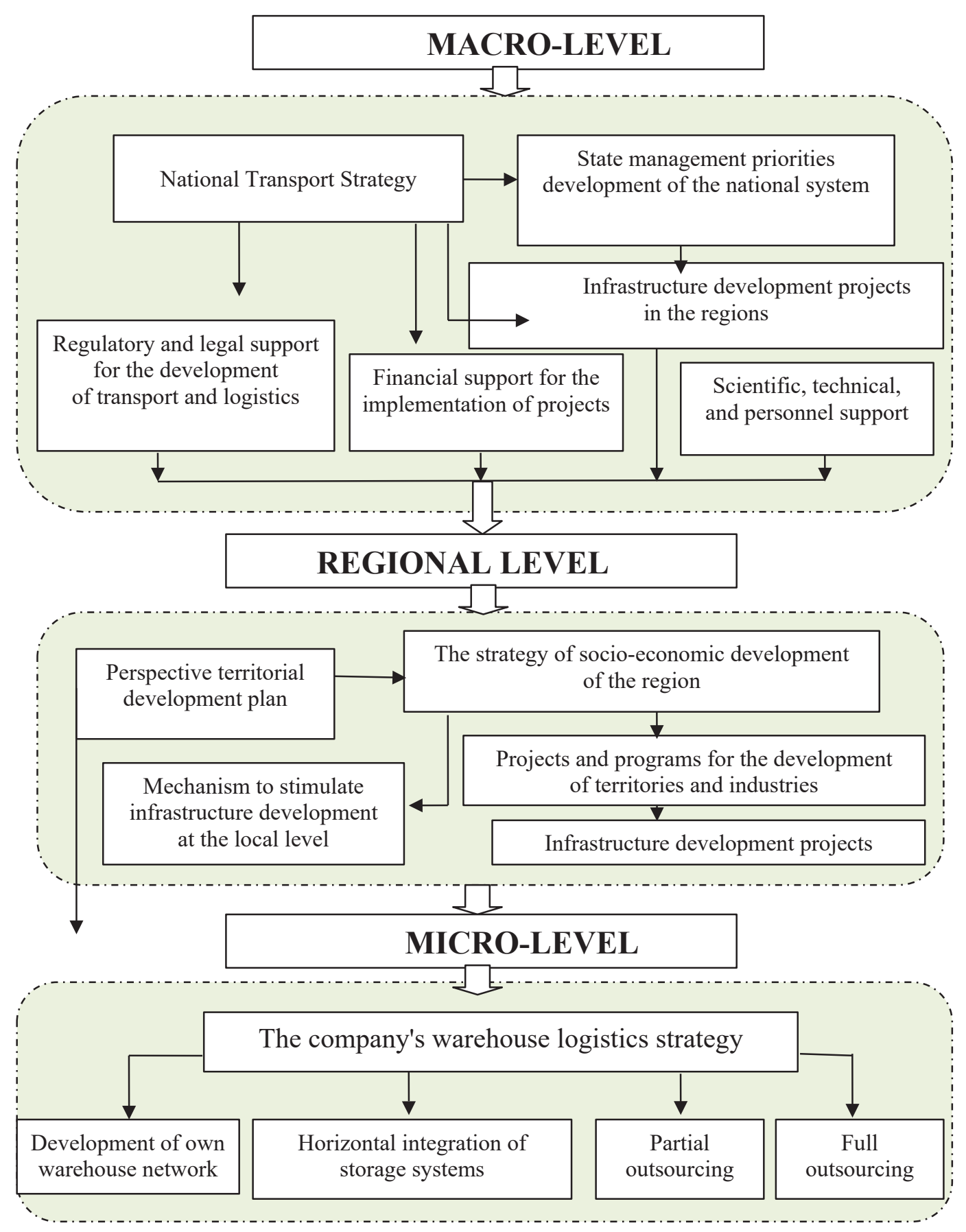

Figure 1. The main components of logistics management development strategy at the macro-, meso- and micro-levels

Source: systematized by the authors

- improving the procedures for the procurement of goods, works and services necessary for the implementation of transport infrastructure projects, in accordance with European practice, taking into account non-price selection criteria, life cycle costs and technical specification requirements;

- for the introduction of information modeling of construction sites to create a regulatory framework;
- assess the results of infrastructure projects by key performance indicators of the implementation of European experience;

- improving the mechanism for implementing investment projects and improving the investment climate financed by international financial institutions;

- providing continuous professional training of employees of state authorities, local governments, 
state-owned enterprises for investment management in modern market conditions.

\section{The formation of a structural model of warehouse logistics development strategy in the region}

The implementation of these measures is designed to encourage investors in the field of transport and logistics infrastructure and unify processes, technologies and procedures in accordance with those in force in the EU.

It is impossible not to agree with the opinion of scientists that "A significant problem in the formation of an integrated logistics infrastructure in the regions, in contrast to developed countries, is the lack of logistics hubs, which can optimally organize the distribution of material flows, inventory management, change of transport, as well as the provision of warehouse services. Logistics centers that meet global standards for cargo handling are an integral part of the logistics infrastructure because they ensure its coordination, integration of circulation and transportation systems, and relationships with manufacturers, carriers, banks, insurance companies and consumers" (Parkhaeva and Kolosova, 2020).
At the regional level, first of all, factors affecting the development of warehouse infrastructure and the development of warehouse logistics services:

- the geographical location and available transport potential of the region;

- the structure of the region's economy, which determines the prevailing specification of warehouses and logistics services;

- the investment climate and the level of interregional integration;

- the level of business activity of business entities in the region.

The main components affecting the development of transport and logistics system of the regions are shown in Figure 2.

Bringing these factors in line with current market needs and growing trends will facilitate the creation and development of logistics systems in the region and individual territories, as well as stimulate business activity in related sectors of the economy - trade, manufacturing, construction and agriculture.

At the micro-level, warehouse logistics strategy of the enterprise is formed as part of the logistics (procurement and warehouse) strategy and depends on the specifics of economic activities, stocks, volume of activities and regional conditions. Based on these

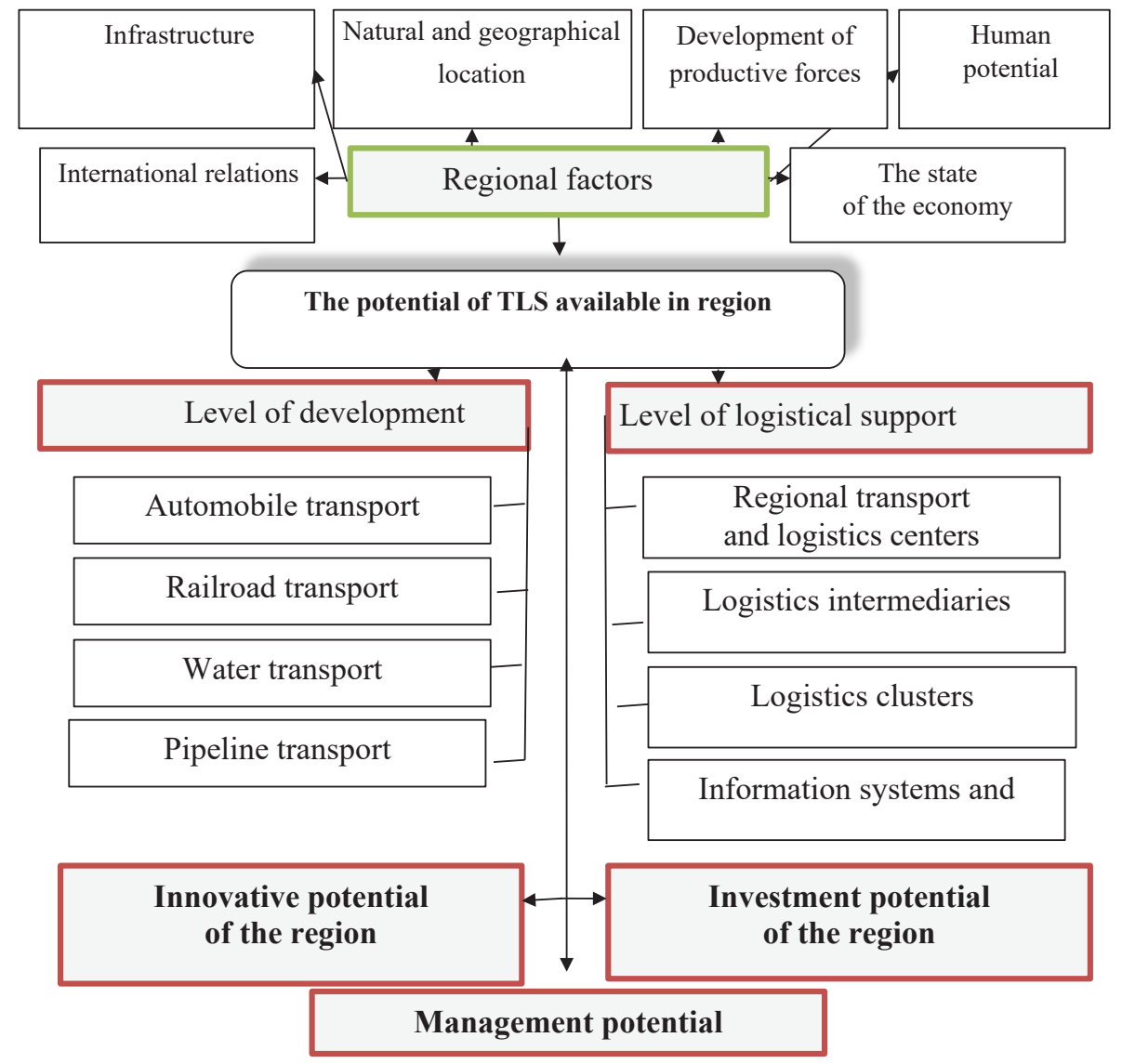

Figure 2. System model to assess the level of development of transport and logistics system in the region 
features, the company as a whole can use one of the general strategies: the construction and use of their own warehouses; production cooperation (integration), partial outsourcing (when opening branches or opening new markets and full outsourcing of warehouse logistics, the strategy of direct delivery.

Thus, the basic principles for the development of warehouse logistics depend on the organization's overall strategy and the corresponding logistics strategy. The main criteria for warehouse logistics in the development of the strategy are the level of logistics costs and the quality of warehouse procedures (storage conditions, inventory placement, labeling, shipment, grouping of goods, accounting).

Researcher Palchyk I. M. notes that "The application and selection of optimal logistics strategies can be based on three key parameters: the planned logistics costs (because they will determine the financial support strategy), the quality of logistics services (this parameter will determine customer satisfaction with the logistics system) and enterprise revenue (the results of logistics strategy)" (Palchyk, 2016).

Based on the study, a generalized definition of the development strategy of warehouse logistics as an integrative component of the management of territorial transport and logistics systems and contributing to the reduction of their logistics costs can be given.

Composite strategies of regional warehouse logistics substantiate the choice of alternatives for placing warehouses in relation to transport and production infrastructure, the number, levels and directions of their specialization, cargo handling technologies, forms and sources of financing construction (modernization) projects, the list of qualification requirements and standards of construction and service provision. Approximately schematically we can reconstruct the model of warehouse logistics development strategy in the regions by structure and attributes (Figure 3). In this case, the specification of individual components and their strategic orientation is determined in accordance with regional specifics, namely the economic structure, geographical location and topography of territories, the role in national and international transport and logistics chains, socio-economic development strategies, long-term development plans, etc.

This model is based on an overall transportation strategy and includes:

1) conditions necessary for the development of storage infrastructure and organization of logistics activities in the region (information, financial, personnel and organizational support), i.e., identified alternatives for organizational and resource support of the storage infrastructure, corresponding to the specifics and strategic priorities of the transport system and the economy as a whole;

2) identified alternatives of the necessary scale and location (for the main transport routes, producers or consumers), the requirements for the technologies used in warehouse logistics and the relevant technical, design, environmental standards for the construction, handling, storage and transportation of goods and the conditions of their insurance and payment;

3) types and forms of organizational links between economic entities, economic and state bodies, subjects of territorial administration, other holders of the state. The development of logistics systems in the regions is facilitated by developed organizational forms of links created on the basis of cluster formations, public-private partnerships and interterritorial agreements.

An important element of the strategy for the development of warehouse infrastructure is to justify the criteria for assessing this type of business in terms of its impact on the economy, social and environmental situation of the region or territories and business

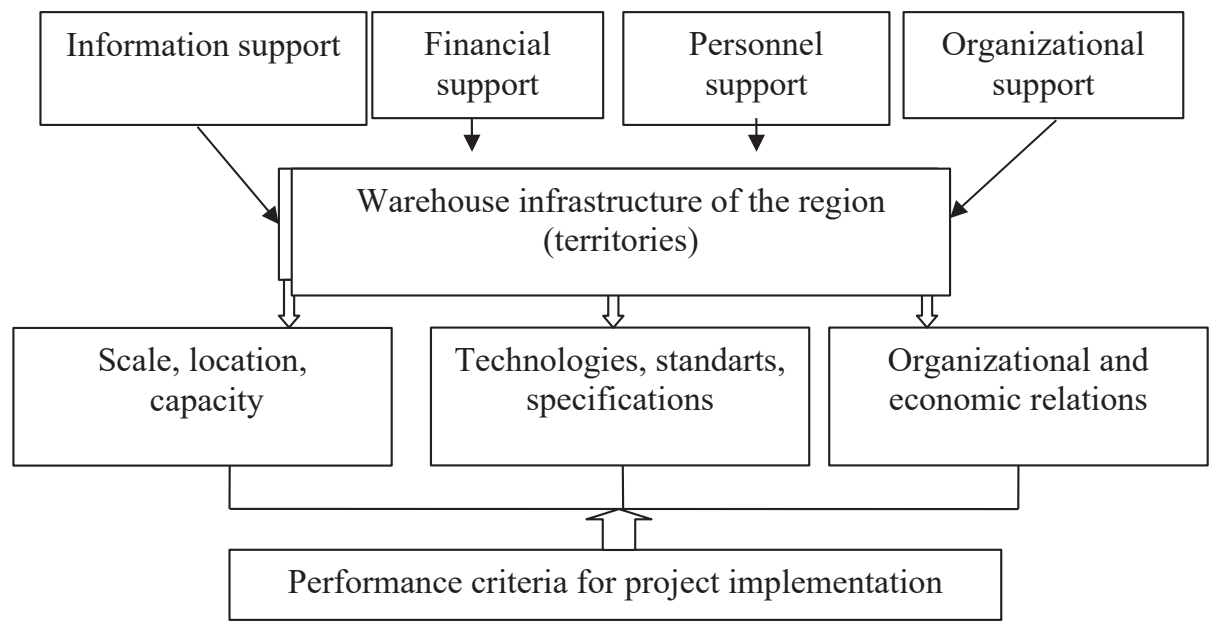

Figure 3. Structural model of the development strategy of regional warehousing logistics

Source: suggested by the authors 
development. Thus, at the regional level, the main criteria for the effectiveness of warehouse logistics can be:

- economic (increased tax revenues, increased business activity, increased investment in the region, increased exports and imports);

- social (increase of population incomes, strengthening of food security, reduction of prices for delivery of goods);

- ecological (placement of storage facilities in areas of no significant value in terms of preservation of regional ecosystems; reduction of environmental pollution; compliance with environmental standards of storage, especially of harmful substances, agriculture and food industry).

The practice of countries with developed economies has proven that the availability of storage facilities and appropriate transport infrastructure in the regions creates a competitive advantage of these territories in terms of attracting investment and opening various types of business. That is why one of the priority directions of development of regional logistics systems is the formation of transport and logistics parks. The advantages of creating transport and logistics parks in the region are obvious, in particular:

- adapting to the trade and production needs of the region will optimize the costs of local producers and trade organizations;

- the establishment in the project of unified standards of European quality, technology, management and environmental safety, which will improve the image of the region in international markets and contribute to the integration of the national economy into the world transport and logistics systems;

- a component of infrastructural support and integration basis for the formation of territorial production clusters;

- promoting the integration of the region into the global logistics chains of e-commerce;

- alignment of economic, socio-economic development of territories through the construction (reconstruction) of transport hubs;

- expanding the volume of foreign economic activity and attracting additional investment to the region;

- creation of new jobs and strategic prospects for the development of human capital.

In addition to regional benefits, the development of warehouse logistics, provided with the appropriate transport infrastructure, will have significant benefits for business, indirectly contributing to its competitiveness in domestic and foreign markets by reducing transport and logistics costs, the timely delivery of products to consumers, reducing the risk of damage. In other words, businesses will have an alternative - to carry out storage and other logistics operations themselves or to use the services of appropriate logistics operators.
At the current stage of the gradual transformation of socio-economic development of regions and the implementation of the reform of budgetary decentralization, there are a number of acute problems associated with the financial provision of social development, guaranteeing social standards for the population, improving the quality of social services. The problems have also been exacerbated by a general economic crisis, military action in the east of the country, and significant political turbulence, which has led to chronic budget deficits, underfunded social programs, and exacerbated social crises (Stehnei, Irtyshcheva \& Gurina, 2018).

The formation of transport and logistics centers in the regions is aimed at the formation of partnerships between producers and consumers of products through a flexible system of interaction between different types of transport and to ensure quality storage of goods and inventory.

In general, the work of the transport and logistics center of the region can be represented as a diagram (Figure 4).

The efficiency and competitiveness of transport and logistics centers is determined by the existing infrastructure, the level of technology and professionalism of services, the level of competence and skills of staff and the digitalization of logistics operations.

Globalization processes have stimulated the formation of a world market, which has greatly increased the need to improve the competitive position of commodity producers (Vyshnevska, Kaliuzhna \& Irtyshcheva, 2019).

Transport and logistics centers act as intermediaries in the organization of interaction between producers and consumers of goods and indirectly influence the business climate in the region, business activity and integration of the region in production and economic relations at various levels.

It should be noted that in recent years the processes of transformation of domestic transport organizations into logistics operators, providing a wider range of logistics services, have been quite active. In addition, there is an active promotion of global logistics companies, which stimulates competition in the industry and promotes the development of business processes. Thus, the top five most powerful logistics companies operating in Ukraine in 2020, according to the Ministry of Transport, included mostly companies with foreign capital: KÜEHNE + NAGEL (Switzerland), DSV LOGISTICS (Denmark), FM LOGISTICS UKRAINE (France), RABEN (Netherlands), EKOL UKRAINE (Turkey). It is worth noting a significant increase in turnover and capital and domestic logistics operators, the most powerful of which are: ZAMMLER, LOGISTIC-PLUS, UVK 


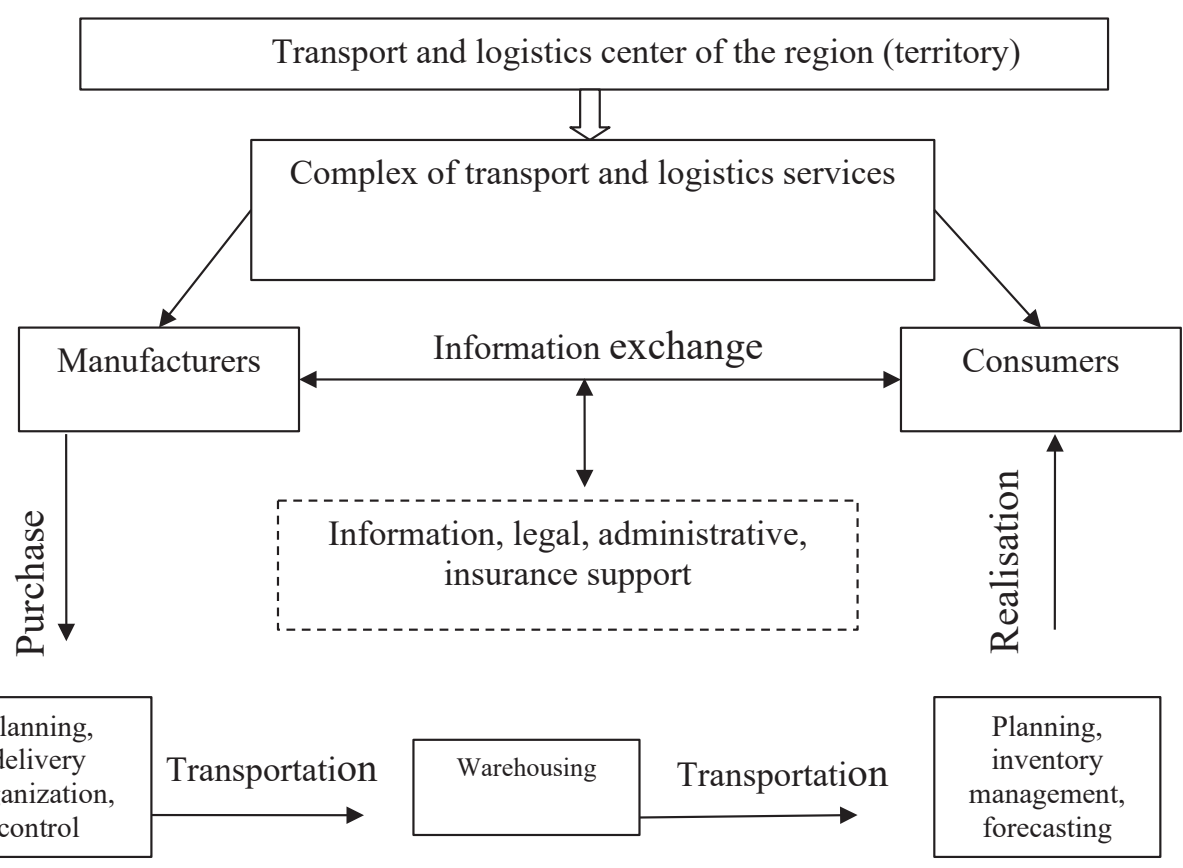

Figure 4. Business processes of transport and logistics services within the transport and logistics centers of the region

Source: summarized by the authors

and PAKLINE LOGISTICS. Each of these logistics companies has its own warehouses of various types in Ukraine and abroad.

Thus, the main areas of development of warehouse logistics, which require increased attention and assistance at the regional level, are:

- implementation of public-private partnership projects in the construction and equipping of warehouses for priority economic activities of the region, which will allow, on the one hand, to receive direct payments to the budget in the form of profit from transport and logistics services and exercise a certain control over the regional economic impact. food and environmental safety, and on the other hand - to attract private investment on a parity basis;

- administrative assistance in the construction (allocation of land, permits, information support) and technological re-equipment of warehouses, provided that investors comply with environmental, technical and other standards;

- the introduction of transparent bidding procedures and public procurement for warehousing logistics services;

- stimulation of investment and innovation activities in the region;

- development of regional training and retraining programs for logistics specialists;

- information and organizational support in the formation and development of regional business structures (clusters, logistics centers, technology parks, etc.).

\section{Conclusions}

It is emphasized that the multiplier effect of investment in transport and logistics does not work by itself, but requires effective management of the regional economy, a high level of business activity in the leading sectors of the regional economy and successful spatial planning. The identified multiplier indicators and their trends in the regions show that investment in the development of transport and, in particular, infrastructure is one of the important incentives for regional economic development. At the same time, the investment gas pedal indicators in dynamics show a downward trend in all regions, which indicates an insufficient level of funding for transport and logistics support against the background of the gradual growth of the regional economy.

Achieving the acceleration and multiplier effect of investment in the transport and logistics sector requires a comprehensive analysis and rational planning of capital investments in the industry, their compliance with the needs and trends of development of the regional, national and world economy. In this regard, an urgent task at the level of regional and territorial administrations is to develop strategies for the development of warehouse logistics as an integrative component of transport and logistics systems. To clarify the nature, main tasks and role in the development of transport and logistics structures in the region offers a structural model of the development strategy of warehouse logistics, which systematizes: the conditions necessary to build a warehouse 
infrastructure and organization of logistics activities in the region; identified alternatives for the necessary scale, location of technologies and communications of storage systems, as well as the types and forms of organizational links between market participants that are directly or indirectly related to these activities.

\section{References:}

Irtyshcheva, I., Ponomarova, M., \& Dolzhykova, I. (2019). Conceptual fundamentals of development of the food security system. Baltic Journal of Economic Studies, 5(2), 57-64. DOI: https://doi.org/10.30525/2256-0742/20195-2-57-64

Official website of the World Bank Available at: https://lpi.worldbank.org/international/scorecard/radar/254/ C/UKR/2016/C/UKR/2014/C/UKR/2012/C/UKR/2010/C/UKR/2007?Sort=asc\&order=Infrastructure\# datatable (accessed May 18, 2021).

Ustenko, M. A., \& Ivashkevich, V. S. (2017). Prospects for the development of transport and logistics systems of Ukraine. Bulletin of Transport Economics and Industry, 59, 84-90.

Parkhaeva, N. V., \& Kolosova, B. V. (2020). Problems and prospects for the development of logistics infrastructure in Ukraine. Available at: http://eir.pstu.edu/bitstream/handle/123456789/5735/\%20.\%20259. pdf? sequence $=1$ (accessed May 19, 2021).

Stehnei, M., Irtyshcheva, I., \& Gurina, O. (2018). Financial mechanism of the socio-oriented economic development of the Black Sea region. Baltic Journal of Economic Studies, 4(4), 202-208. DOI: https://doi.org/ 10.30525/2256-0742/2018-4-4-202-208

On approval of the National Transport Strategy of Ukraine for the period up to 2030 (2021). Available at: https://zakon.rada.gov.ua/laws/show/430-2018-\%D1\%80\#Text (accessed May 19, 2021).

Sustainable Logistics Strategy and Government Action Plan (draft for consideration) (2021). Available at: https://mtu.gov.ua/files/Logistics.pdf (accessed May 19, 2021).

Strategy for reforming the life cycle management of the infrastructure project in Ukraine for 2020-2024 (2021). Available at: https://mtu.gov.ua/content/investoru.html (accessed May 19, 2021).

State Strategy for Regional Development for 2020-2027 (2021). Available at: https: / /www.kmu.gov.ua/npas/prozatverdzhennya-derzhavnoyi-strategiyi-regionalnogo-rozvitku-na-20212027-t50820 (accessed May 19, 2021).

Vyshnevska, O., Kaliuzhna, O., \& Irtyshcheva, I. (2019). Infrastructure provision of the agrarian market in the globalized environment. Baltic Journal of Economic Studies, 5(5), 39-46. DOI: https://doi.org/10.30525/22560742/2019-5-5-39-46

Palchyk, I. M. (2014). Formation of logistics strategy of the enterprise in modern business conditions. Efficient economy, 11. Available at: http://www.economy.nayka.com.ua/ ?op=1\&z=3575 (accessed May 20, 2021).

Ministry of Transport (2021). Available at: https://mintrans.news/logistics/top-10-naybilshikh-logistichnikhkompaniy-ukraini (accessed May 20, 2021). 